\title{
Visegrad Group and Relations with Russia
}

\author{
R. Višňovský \\ Saint-Petersburg State University, St. Petersburg, Russian Federation
}

\begin{abstract}
This article refers to the Central European countries by meaning the Visegrad Group countries (V4) Hungary, Czech Republic, Poland, and Slovakia. The development of the Visegrad Group aimed on integration to the Euro-Atlantic structures fulfilled its promise, nevertheless, the membership in Western structures does not necessarily mean the loss of Russian influence in the region of Central Europe. On the contrary, the region's connection to Russia developed in the past remained to some extent even after the process of political transition in particular countries. Such connections are responsible for foreign policy discourse with a plethora of questions and misunderstandings on issues related to the political attitudes of Visegrad members towards Russia and some contradictory stances of the V4 countries among themselves as well with respect to Brussels. The EU's politics of sanctions towards Russia is having a direct, counterproductive effect in Visegrad, what is resulting in undermined relations and weakened coherence inside the EU with the emergence of anti-Western and pro-Russian political parties that creates the space for Russian foreign policy to achieve more influence in the region. This article is analyzing the background of such discourse and some of the reasons behind the pro-Russian sentiment or discrepancies and non-coherence of the EU members' opinions on Russia. At the same time, the awareness of the outcomes of this article can be relevant in analyzing the possibilities to avoid the deepening of the conflictual foreign policy between the EU and Russia, or the Visegrad and Russia, respectively. The research is built on both, primary and secondary sources, related mainly to the evolution of relations in specific areas between both sides. The mentioned historical perspective creates the basis of the analysis and is further put into contemporary discourse to find the answers on the question: what are the reasons for non-coherence of the EU and Visegrad towards the policy against Russia? To achieve the above-mentioned results, the analysis is provided in chronological perspective using the mixed methods by exploring the official documents, scholarly articles published on the topic, and public polls as well.
\end{abstract}

Key words: Visegrad Group, Central Europe, Russia, European Union, foreign policy, influence, non-coherence

For citation: Višňovský, R. (2020). Visegrad Group and Relations with Russia. Vestnik RUDN, International Relations, 20 (2), 347-355. DOI: 10.22363/2313-0660-2020-20-2-347-355

Научная статья

\section{Вышеградская группа и отношения с Россией}

\section{Р. Вишнёвский}

Санкт-Петербургский государственный университет, Санкт-Петербург, Российская Федерация

Объединение стран Центральной Европы в Вышеградскую четверку (в составе Венгрии, Чехии, Польши и Словакии) после распада социалистического блока, нацеленное на дальнейшую интеграцию в евроатлантические структуры, оправдало ожидания, в то же время вступление этих стран в западные военно-политические структуры необязательно означает потерю влияния России в данном регионе. Напротив, созданная в прошлом связь региона с Россией в некоторой степени сохранилась и после процесса политического перехода в отдельных странах. Такого рода связь определяет наличие множества вопросов и недоразумений во внешнеполитическом дискурсе

(C) Višňovský R., 2020

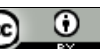

This work is licensed under a Creative Commons Attribution 4.0 International License.

https://creativecommons.org/licenses/by/4.0/ 
как в отношении политики стран Вышеградской группы (V4) к России, так и в случае взаимодействия стран V4 между собой или же в отношении Брюсселя. Политика санкций, проводимая ЕС в отношении России, имеет контрпродуктивный эффект в случае стран Вышеградской четверки, что приводит к ослаблению согласованности внутри Европейского союза, а также появлению антизападных и пророссийских политических партий, создавая пространство для достижения большего влияния России в регионе. В статье анализируются предпосылки появления подобного политического дискурса, а также некоторые причины, лежащие в основе пророссийских настроений, расхождений и несогласованности мнений членов ЕС в отношении России. В то же время выводы, сформулированные по итогам данного исследования, могут быть актуальны при анализе возможностей избежать усугубления конфликтов во внешней политике между ЕС и Россией или стран Вышеградской группы и Россией. В исследовании были использованы как первичные, так и вторичные источники, касающиеся главным образом эволюции отношений в конкретных областях между сторонами. Упомянутый исторический подход создает основу для анализа, который в дальнейшем рассматривается в рамках современных реалий с целью поиска ответов на вопрос о причинах несогласованности позиций ЕС и стран Вышеградской четверки относительно России. С целью достижения вышеуказанных результатов анализ представлен в хронологическом порядке с использованием различных методов путем изучения официальных документов, научных статей, опубликованных по этой теме, а также социальных опросов общественного мнения.

Ключевые слова: Вышеградская группа, Центральная Европа, Россия, Европейский союз, внешняя политика, влияние, несогласованность

Для цитирования: Višňovský $R$. Visegrad Group and Relations with Russia // Вестник Российского университета дружбы народов. Серия: Международные отношения. 2020. Т. 20. № 2. C. 347-355. DOI: $10.22363 / 2313-0660-2020-20-2-347-355$

\section{Historical Perspective on Russia - Visegrad Relations}

To understand the nature of relations between Russia and Visegrad countries, it is inevitable to take a look at the historical background of the two's affiliation. The common experience of the Visegrad Group countries with their communist past and their existence under the influence of the USSR since the end of the Second World War until late 1989 has left huge "heritage" and interconnections on the postSoviet regions including the leading successor of the USSR - the Russian Federation. To overcome the negatives and to adapt on a new, democratic political system in association with Western Europe [Marušiak 2013b: 31] more smoothly, Czechoslovakia, Hungary, and Poland decided in 1991 to establish the Visegrad Group, however, its formation was "particularly influenced by Austria's lack of interest in developing of a partnership with the democratizing postCommunist states of Central Europe" [Cabada 2018: 170]. This coalition, since the split of Czechoslovakia also known as the V4, was important not only for a transition process of the political system in the member countries but its foundation was aimed also to become beneficial for integration into the Euro-Atlantic structures like NATO and the European Union ${ }^{1}$. Restitution of democratic system, acquiring the economic and political relations with the West and diversifying the energy sources from Russia can be assumed as a political "restart" aimed to begin a new chapter without the influence of Russia; nevertheless, it was not as obvious. Mentioned processes were not in every V4 country as smooth as one would depict, mainly due to the different ideas of political representatives on further development mainly in regard to foreign policy and relations with Russia.

This is related primarily to the case of Slovakia and the ideas of its prime ministers until 1998. During the short period of the federative state of Czechs and Slovaks (1990-1992), the Prime Minister of Slovakia Ján Čarnogurský (1991-1992) was not a strict proponent of Western integration mainly in terms of NATO membership, rather, his view was linked with the idea of bridge between East and West with Slovak EU membership and closer cooperation

\footnotetext{
${ }^{1}$ Unofficial translation of Declaration on Cooperation between the Czech and Slovak Federal Republic, the Republic of Poland and the Republic of Hungary in Striving for European Integration, 1991 // Visegrad group. URL: http://www.visegradgroup.eu/documents/visegraddeclarations/visegrad-declaration-110412 (accessed: 20.11.2019).
} 
of "Slavic Europe" and Russian Federation [Marušiak 2015: 32]. Such an identity-oriented idea of political cooperation with Russia was later partly followed by Čarnogursky's successor Vladimir Mečiar, the Slovak head of government until 1998. Nevertheless, the foreign policy of Slovakia during Mečiar's rule had among the key points the EU and NATO accession [Marušiak 2013a: 45], however, the prime minister was not eager enough to find the way of Slovakia from the Russian - mainly economic dependence, furthermore, he rather became inspired by nontransparent privatization and undemocratic tendencies as strong state control of the massmedia or using of power structures for his political aims - authoritarian tendencies that were prevalent in post-communist space with Russian influence [Cameron, Orenstein 2013: 2]. Thus, thanks to Mečiar's government Slovakia earned the status of "deviant country in Central Europe" [Szomolányi 2004: 149] and his foreign policy orientation was in a part responsible for the shifting of Slovakia closer towards Russia [Dangerfield 2012: 961].

\section{The Soviet and Russian Foreign Policy towards Visegrad Group Countries after 1989}

In fact, the mentioned "development" in Slovakia until the end of Mečiar's government in 1998 was in a part successful foreign policy of the USSR, and later of Russia as its successor state after the fall of the Soviet Union in 1991. This assumption is connected partially to the "Kvitsinsky doctrine" 2 at the beginning of the 1990s which was aimed at foreign and security policy of the former Soviet satellite states of Central Europe to prevent their membership in security alliance of the West after the dissolution of Warsaw Treaty, and so they should create a buffer zone between the NATO and the USSR, Russia respectively [Duleba 1998: 24].

\footnotetext{
${ }^{2}$ Kvitsinsky doctrine named after the Deputy Minister of Foreign Affairs of the USSR Yuliy Kvitsinsky. According to Duleba [1998: 24] this policy can be summed as: the countries of Central Europe cease to be Soviet satellites, and as sovereign actors of international relations should agree with the status of a buffer zone between NATO and USSR.
}

However, the Visegrad countries Czechoslovakia, Hungary, and Poland signed new treaties with Russia as a successor of the USSR in 1992, but they refused to include such security provisions in the new bilateral treaties and prevented the implementation of the "Kvitsinsky doctrine" in practice. Nevertheless, the new political situation after the split of Czechoslovakia in 1993 allowed Russian foreign policy to follow some patterns similar to the "Kvitsinsky doctrine" mainly in Slovakia. These patterns are referring more precisely to the "Kozyrev doctrine" adopted by Russia in 1992 - 1993, which aimed on same security issues of Central European countries intending to prevent of expelling Russia's interests from region, and in contrary to "Kvitsinsky's", the "Kozyrev's doctrine" should avoid of creating of buffer zone in Central Europe that would isolate Russia from the West.

The new treaty that Slovakia signed with Russia lacked the coordination with its Visegrad partners what compelled Slovakia to "accept the Russian ideas on the way of building up the European security architecture" and make it more difficult for Slovakia to try and accede to the Western security structures [Duleba 1998: $30-31]$.

Moreover, there was also another economic instrument of Russia's foreign policy to influence some developments in Central Europe. This is connected to unresolved economic issues like Soviet financial debt to the V4 countries stemming from The Council for Mutual Economic Assistance (COMECON) cooperation which was after the split of the USSR transferred on Russia. The debt consisted of around 3.5 billion USD to the Czech Republic, 1.7 billion USD to Hungary, and 1.6 billion USD to Slovakia, while Russia offered to pay it by deliveries of military components [Duleba 1998: 92]. The Czech Republic has refused to sign such compensation of the Soviet debt keeping in mind its future in NATO, while Hungary agreed, and

3 Kozyrev doctrine named after Russian Foreign Minister Andrei Kozyrev, promoted a pro-Western approach, expecting Western assistance in Russia's transition to democracy, its development of market economy and treating Russia as an equal partner by the West [Sangtu 2006: 149]. 
its dual armaments supplies, both, from the West and Russia was acceptable for NATO membership. On the contrary, Slovakia, during Mečiar's government accepted Russia's offer for refunding its debt by military deliveries, however, under very obscure circumstances, as Duleba states: "The debt is paying off by the Russian government to Russian business companies in the Slovak Republic" [Duleba 1998: 93]. Nevertheless, the rest of the debts owed to Visegrad countries from Soviet era were refunded by Russia until the end of $2013^{4}$, and as it was outlined, a part of the debt to Slovakia was returned in various commodities among which were also military supplies or upgrades of the MiG-29 jet fighters ${ }^{5}$.

The government of Vladimir Mečiar together with accepting the "Kozyrev's doctrine" led to the fact that Slovakia did not join the NATO in 1999 in contrary to its Visegrad partners which were in the signing of bilateral agreements with Russia more cautious. The foreign policy under the "Kozyrev's doctrine" clearly illustrates Russia's security issues and its opposition towards the possibility of NATO enlargement in Central Europe [Racz 2014: 65] as well it indicates the patterns of Russia's European policy [Póti 2006: 117].

\section{Visegrad Towards the Joining of the EU and NATO}

The results of Slovak parliamentary elections in 1998 has brought a new government composed of democratically oriented political parties [Szomolányi 2000: 77] that were more inclined towards the EU and NATO membership, hence its foreign politics was oriented primarily on the West. Slovak aspiration for membership in Euro-Atlantic structures was supported also by the rest of its partners in the V4 (mainly by Poland) whose membership at that time was just a question of a formal act and

\footnotetext{
${ }^{4}$ Russia Pays Off \$2B Soviet Debt to Serbia, Slovakia // Sputniknews. 18.06.2013. URL: https://sputniknews.com/ world/20130618181739594-Russia-Pays-Off-2B-SovietDebt-to-Serbia-Slovakia/ (accessed: 22.11.2019).

${ }^{5}$ Money from Russian debt to upgrade Slovak MiG-29s // The Slovak Spectator. 13.02.2004. URL: https://spectator. sme.sk/c/20021558/money-from-russian-debt-to-upgradeslovak-mig-29s.html (accessed: 22.11.2019).
}

their support of Slovakia as the wish for revitalizing the Visegrad cooperation [Marušiak 2015: 33]. However, the Washington Summit in 1999 granted the NATO membership only to the rest of Visegrad Group and Slovakia obtained only the aspirant status - as it had just a very little period to provide changes in its politics after Mečiar's government.

After the NATO enlargement by the Czech Republic, Hungary and Poland in 1999, Russian foreign policy experts understood that this process is irreversible and that the new way of cooperation strategy in the region of Central Europe is needed. Despite the establishment of Russia's quasi-member status created by the 1997 NATO - Russia Founding Act on Mutual Relations, Cooperation and Security have renewed Russia's place on the security constellation in Europe, however, it does not granted Russia any veto power [Blank 1998: 118] what has been demonstrated by 1999 Kosovo crisis. Furthermore, even granted the veto power of Russia in the UN's Security Council did not prevent the military action of NATO in Kosovo what meant Russia's deeper isolation from the development of security in Europe. NATO's eastward expansion has brought direct opposition from the Russian side as it existentially concerned its security issues. This assumption is developed on the content of The Basic Provisions of the Military Doctrine of the Russian Federation approved by Boris Yeltsin in 1993 that is referring to the list of "key external military dangers to Russia, the expansion of military blocks and alliances" [Fedorov 2013: 319].

The period until 2000 was significant for the struggle of foreign policy dominance between Russia and Euro-Atlantic structures to establish their ideas on security policy in the European, post-Soviet region [Gerasymchuk 2014: 44]. The success of NATO enlargement indicates the loss of Russian dominance in the region, and according to this, the relations between Russia and the V4 after 2000 could be understood more or less only in pragmatic, and economic means with Russia's intentions to attain more influence on the energy market of Visegrad countries. 


\section{Russia and Visegrad's Energy Market}

Since it was clearly sure that Slovakia will join its Visegrad partners in NATO in next enlargement in 2004, and accordingly, Russia has lost in this perspective its effect on security issues and military export even more with regards to fact that the V4 countries and its armed forces will sooner or later rearm its equipment on Western, NATO-compatible units. Therefore, enhancing the influence on the energy market together with the economic sector of Central Europe remained the most vital objective for Russia in order to maintain its presence in the Central European region.

Thanks to the Soviet development of energy infrastructure in the Central European countries during the communist period, it was not a very hard task for Russia to achieve influence on the V4 countries' energy markets even after the postcommunist political transition. The existence of the "Yamal" gas-pipeline in Poland and the "Brotherhood" gas-pipeline in the Czech Republic and Slovakia, both stemming in Russia, is crucial for gas deliveries not only for the Central European region but for the other European countries as well. Together with the "Druzhba" (Friendship) oil-pipeline crossing through all Visegrad countries it makes a very vulnerable tool of Russian foreign policy in the region, with the effect on the whole EU, thus, the energy security is a major theme of the Visegrad Group [Fawn 2014: 12]. However, each of the V4 countries is dependent on these deliveries to a different extent $^{6}$ the existence of such energy interconnections is creating space for Russian foreign policy having an impact on the countries in the region by bargaining through Russian energy companies.

This has been proved for instance during the 2009 gas crisis when Russia stopped deliveries of natural gas to Ukraine [Mišík 2012: 69]. The

6 Czech Republic - 99.2\%; Hungary - 95.0\%; Slovakia - 84.6\%; Poland - $65.6 \%$ from Natural gas imports from Russia in 2017 // EUROSTAT. URL: https:/ec.europa.eu/eurostat/cache/infographs/energy/bloc2c.html (accessed: 25.11.2019); Slovakia — 74.0\%; Poland - 68.5\%; Hungary - 42.7 \%; Czech Republic $35.2 \%$ from Imports of crude oil from Russia in $2017 / /$ EUROSTAT. URL: https://ec.europa.eu/eurostat/cache/ infographs/energy/bloc-2c.html (accessed: 25.11.2019). disruption meant that no gas from Russia was further delivered to Europe via Ukraine for 11 days, as a result of disagreement over the gas prices between Russia and Ukraine. Among the Visegrad countries, this crisis harmed the most to Slovak economy, which lost around 1 billion EUR subsequently to limited or halted production in factories [Tarnawski 2015: 132], while Slovak prime minister, Robert Fico accused the Ukrainian side from responsibility of such situation and called for drawing of political consequences with regards to Slovak support of Ukrainian ambitions to Euro-Atlantic integration [Duleba 2009: 5]. This allowed to Russian companies to dictate the conditions about the gas deliveries, thus to shape and influence the politics in the region of Central Europe and to some extent with outcomes towards the whole EU.

Nevertheless, the gas crisis has forced the V4 countries to find the possibilities of reshaping its energy security policy and to develop alternative sources of energy deliveries, less dependent on Russia. Despite the establishing of various policies for this purpose like Energy infrastructure priorities for 2020 and beyond, or Central and South-Eastern Europe Energy Connectivity (CESEC) as well developing several projects like Nabucco pipeline or Eastring pipeline, and Trans Anatolian Gas Pipeline (TANAP) or Trans Adriatic Pipeline (TAP) with various degree of success, it does not allow the Visegrad Group and the whole EU, in general, to become sufficiently independent on the energy sources from Russia. While the crude oil deliveries from Russia have decreased, however, not very significantly ${ }^{7}$, yet, the effectiveness of these policies is doubtful, as some Visegrad countries became even more dependent on Russian natural gas ${ }^{8}$. The period

${ }^{7}$ For comparison, match the numbers from previous page with - Imports of crude oil from Russia according to EUROSTAT 2009: Slovakia — 81.9\%; Hungary $78.0 \%$; Poland - 74.6\%; Czech Republic - 49.8\% // EUROSTAT. URL: https:/ec.europa.eu/eurostat/cache/ infographs/energy/bloc-2c.html (accessed: 25.11.2019).

8 Natural gas imports from Russia according to EUROSTAT 2009: Slovakia — 99.3\%; Hungary $82.7 \%$; Poland - 82.0\%; Czech Republic - 65.4\% // 
after the gas crisis and the EU's extensive search for alternative sources of energy has brought also addressing attention away from significant issues in relations between the EU/Visegrad and Russia - the development of EU's Eastern Partnership, described by Russia as an unfriendly gesture [Shishelina 2015: 72].

\section{Russian Political Discourse in Visegrad Countries after the Ukrainian Crisis}

The crisis in relations between the EU and Russia after the Ukrainian president Yanukovych refused to sign the Association Agreement with the EU in 2013 has brought some questions on the level of EU's cohesion. The representatives of some EU member states reflected contradictory stances on the Ukrainian crisis and different levels of support towards the antiRussian sanctions, while the same applies to the case of Visegrad Group which was among the EU's regional factions the most skeptical to the political solution of crisis adopted by the EU. Except for Poland, the rest of the V4 members were reluctant to agree with Brussels on politics towards Russia what led into polarization of society [Stojarová 2018: 42] and misusing of political campaigns by various domestic political parties and movements of particular states to spread their pro-Russian, anti-Western ideologies [Gressel 2017: 3], with perception to achieve the sympathies of potential voters and to legitimize their actions [Sydoruk, Tyshchenko 2016: 25].

Finally, the governments of the Visegrad countries agreed on sanctions since 2014, however, each round of new sanctions has brought more objections from the representatives of the Czech Republic, Hungary, and Slovakia [Kucharczyk, Mesežnikov 2015: 12]. For instance, Czech President, Miloš Zeman stated that "sanctions are an expression of helplessness", or Hungarian Prime Minister Viktor Orbán evaluated the sanctions in 2014 as "In politics, this is called shooting oneself in the

EUROSTAT. URL: https://ec.europa.eu/eurostat/cache/ infographs/energy/bloc-2c.html (accessed: 25.11.2019).

9 The V4 Will Never Agree on Russia // EURACTIV. URL: https://www.euractiv.com/section/central-europe/ news/the-v4-will-never-agree-on-russia/ 02.12.2019). foot"10, while the Slovak Prime Minister (until 2018) Róbert Fico has repeatedly called for stop of the sanctions, for example with the statement like "nonsensical and harmful"11. The main reasons behind such statements of three Visegrad countries are certainly in economic and energy issues, and it illustrates that some Visegrad representatives are ambitious for pragmatic and efficient cooperation with Russia [Dangerfield 2012: 971]. After all, in a long-term historical perspective of cooperation, such opinions of Central European leaders on anti-Russian sanctions should be viewed as a natural and predictable outcome [Dangerfield 2015: 3]. Nonetheless, the next paragraph will illustrate another interesting phenomenon related to civic society that is affecting the distinct or specific affiliation of Central European countries towards Russia, an aspect that cannot be overlooked by politicians of particular governments, thus it is shaping their foreign policies as well.

\section{Public Opinion on Russia among the Visegrad Member States}

The most comprehensive public opinion poll up to date, realized by the Visegrad countries for the purpose of highlighting its administration after twenty-five years of cooperation ${ }^{12}$, will help us to understand some foreign policy trends of Central European countries towards Russia. Supplemented with the poll called "Trends of Visegrad Foreign Policy"13 conducted in 2015,

10 Hungary PM Orban condemns EU sanctions on Russia // BBC News. URL: https://www.bbc.com/news/ world-europe-28801353 (accessed: 02.12.2019).

11 Fico: If USA Scraps Russia Sanctions, EU Might Pluck Up Courage // NewsNow, The News Agency of the Slovak Republic. URL: https://newsnow.tasr.sk/foreign/ fico-if-usa-scraps-russia-sanctions-eu-might-pluck-upcourage/ (accessed: 02.12.2019).

1225 Years of the V4 as Seen by the Public - Project coordinated by the Institute for Public Affairs in Bratislava, analyzed the data from a representative sample of adult population of the four countries, gathered by following research agencies: STEM (Czech Republic), Tárki (Hungary), Stratega Market Research (Poland) and Focus (Slovakia). URL: http://www.visegradgroup.eu/ documents/essays-articles/25-years-of-the-v4-as (accessed: 04.12.2019).

13 Trends of Visegrad Foreign Policy - Project supported by the Konrad Adenauer Foundation, the Ministry of Foreign Affairs off the Czech Republic and the 
the poll "25 Years of the V4 as Seen by the Public" has questioned citizens of the four countries not only about their awareness of domestic and inter-Visegrad issues but it also conducted research about foreign issues of the V4 with respect to organizations like NATO, the EU or other partners and allies outside the Visegrad and Euro-Atlantic structures. However, for the purpose of this analysis, we will use only data that are related to Russia.

According to the research, citizens of Slovakia (as a most strongly integrated Visegrad country with the EU in the institutional dimension [Pakulski 2016: 80]) expressed the highest level of trust towards Russia among the Visegrad countries. Answering the question: "To what extent can we trust and rely on the following nations?" (responses "definitely trust + rather trust" and "rather distrust + definitely distrust" are merged, without neutral responses "neither trust nor distrust" and "don't know", in \%, expressing the trust to the V4 countries + Austria, Croatia, England, France, Germany, Russia, Slovenia, and Ukraine [Gyárfášová, Mesežnikov 2016: 20]) as much as $31 \%$ of Slovaks expressed their trust towards to Russia, achieving the 8th place in their rankings, with Czech Republic on the first place, obtaining $78 \%$. What is more interesting on these results is the fact that Russia earned more trust than the V4 member - Hungary (30\%) and more than one of the NATO establishment initiator - the USA ( $27 \%$ ), or Slovakia's neighbour - Ukraine (17\%). Evaluation of trust towards the Russia by the other V4 countries was quite different, whereas, except for the Poland where Russia obtained the last place with only $9 \%$ of trust following the Ukraine (29\%), in Hungary with $16 \%$ and in the Czech Republic $17 \%$ of citizen's trust, Russia achieved the 11th place, in both cases before Ukraine (14 and $13 \%$ respectively).

With respect to the poll "Trends of Visegrad Foreign Policy" provided on civil servants,

Open Society Foundations. It has been carried out in cooperation with the Center for EU Enlargement Studies CENS (Hungary), the Central European Policy Institute CEPI (Slovakia) and the Institute of Public Affairs - IPA (Poland). Via questionnaire, the project approached civil servants, experts, researchers, journalists, business and political representatives from Visegrad Group countries. URL: https://rendyv4.amo.cz/ (accessed: 04.12.2019). political representatives, etc., the findings are more remarkable. For example, on the question "Which countries are the 5 most important partners for your country's foreign policy?" [Dostal 2015: 22] — for Visegrad Group in general, Russia achieved sixth place with $39.1 \%$, while for Hungary itself it occupied a significant third place with $73.3 \%$ behind Germany and the USA. With the task to evaluate the importance of the countries from the list (the V4 + Austria, China, France, Germany, Israel, Lithuania, Romania, Russia, Serbia, Sweden, Turkey, Ukraine, and United Kingdom) with respect to particular Visegrad members, in general, the V4 evaluated the importance of Russia on the 4th place with $67.1 \%$ in average, with the biggest significance in Hungary $(81.4 \%)$. However, to evaluate the quality of the V4 countries' relations with the countries from the mentioned list, Russia achieved the worst mark on a scale of 1 to 5 ( 1 for very good and 5 for very bad) with 3.3 in average, with the best result in Slovakia (2.7).

Keeping in mind the dependence on energy security policy of the Visegrad Group from Russia, altogether with possible eagerness of the representatives of the V4 (except Poland) to cooperate with Russia in pragmatic, efficient way as indicated in previous paragraph, it is no surprise that energy security is going to be the issue No.1 for their countries in the next five years - what is demonstrated in the poll by achieving the first place (on the question - How important will the following issue be for your country's foreign policy in the next 5 years?) with $86.3 \%$ for the Visegrad in general, while in Poland it achieved the highest value (90,4 \%) [Dostal 2015: 28].

\section{Conclusion}

There is no common political stance or integrated foreign policy that reflects the substantial relations of the Visegrad Group towards Russia unanimously from Brussels, and which is similar for instance to the policy within the EU related to anti-Russian sanctions. The analysis proved that there are specific relations and opinions of single Visegrad countries that are different from the official EU-Russian discourse. These principles are built in most cases on pragmatic political issues and developed throughout the historical interconnections with 
contemporary effects and relations mainly in economic terms. Analysis showed that there are positive tendencies among the citizens and representatives of Visegrad, that are calling for cooperation with Russia what can be assumed as a source of EU's non-coherence, however, the lack of consensus on Russia and deficient of common foreign policy of the V4, together with prioritization of the Brussels' decisions above national - foreign policies in particular Visegrad countries makes it difficult to achieve full potential from this cooperation.

With exception of Poland, as the only Visegrad country which probably (and the most certainly) did not overcame the historical animosities with Russia, the polls have discovered the reasons (and potential) behind the "struggle" between domestic political parties of particular states, from leftist, nationalistic, antiWestern and conservative political spectre that manifests more sympathies towards Russia. These parties, stimulated by the principles of dissatisfaction towards the foreign policy of Brussels, nourished on anti-migration and proRussian discourse are standing against centralright, (neo)-liberal, West-oriented political spectre that is more or less anti-Russian adapted. Therefore, the context and course of the foreign policies of the both, the West, and the Russian Federation will be instrumental for shaping of the political discourse in the region of Central Europe that will influence the public opinion, the campaigns of the political parties, potential voters, and last but not least, the governments. Positive stances on Russia by the Hungarian president Viktor Orbán, pro-Russian sentiment of the Czech president Miloš Zeman, or negative attitudes towards anti-Russian sanctions of leading Slovak political parties like the Direction-Social Democracy (SMER-SD) or Slovak National Party (SNS) together with the rising popularity of populist, anti-Western party like "Kotleba-People's party our Slovakia" (Kotleba-LSNS) can lead Poland to exit the cooperation within the Visegrad, and at the same time, the course of national, anti-Western and pro-Russian politics or anti-Russian, proWestern campaigning will have a crucial effect on the future development of relations between the Visegrad and the EU, the Visegrad and Russia, or between EU and Russia. Thus, prevention of EU's conflictual foreign policy discourse with Russia would be essential to alleviate tensions inside the EU, and to achieve more pragmatic relations with Russia, enabling the prospects for a win-win scenario.

Nevertheless, there is still Russian foreign policy with its specific instruments to play in the region of Central Europe but more importantly in the region of the EU's Eastern Partnership (EaP) as it is not fully integrated into the Euro-Atlantic structures yet. In shaping of its foreign policy in the EaP region, it can overcome its faults from past, however, space for manoeuvring and cooperation is by deepening of Russian isolation in context of sanctions shrinking, thus it depends only on calculations of Russian foreign experts how the country would use its inventory and whether there are any other possibilities to prevent unwanted scenario - Russia's loss of the influence in the region and even more isolation from the West.

Received / Поступила в редакцию: 18.02.2020 Accepted / Принята к публикации: 15.04.2020

\section{References / Библиографический список}

Blank, S. (1998). Russia, NATO Enlargement, and the Baltic States. World Affairs, 160 (3), 115-125.

Cabada, L. (2018). The Visegrad Cooperation in the Context of Other Central European Cooperation Formats. Politics in Central Europe, 14 (2), 165-179. DOI: 10.2478/pce-2018-0014

Cameron, D. \& Orenstein, M. (2013). Post-Soviet Authoritarianism: The Influence of Russia in Its "Near Abroad". Post-Soviet Affairs, 28 (1), 1-44. DOI: 10.2747/1060-586X.28.1.1

Dangerfield, M. (2012). Visegrad Co-operation and Russia. Journal of Common Market Studies, 50 (6), 958 -974. DOI: $10.1111 / \mathrm{j} .1468-5965.2012 .02295 . \mathrm{x}$

Dangerfield, M. (2015). Economic Relations between Visegrad Group Countries and Russia: How Much Has Changed? EUSA Fourteenth Biennial Conference, 5-7 March. URL: https://pdfs.semanticscholar.org/ 3c4a/b82c63fa56f9719920f995e7f463c6cf566e.pdf?_ga=2.83412502.182790737.1581971339-1630200980. 1581971339 (accessed: 25.11.2019). 
Dostal, V. (2015). Trends of Visegrad Foreign Policy. Prague: Association for International Affairs. P. 1-69. URL: http://www.amo.cz/wp-content/uploads/2015/11/Trends-of-Visegrad-foreign-policy.pdf (accessed: 25.11.2019).

Duleba, A. (1998). From Domination to Partnership: The Perspectives of Russian - Central-East European Relations. Final Report to the NATO Research Fellowship Program, 1996-1998, 1-118.

Duleba, A. (2009). Poučenia z plynovej krízy v januári 2009. Analýza prićin vzniku, pravdepodobnosti opakovania a návrhy opatrení na zvýšenie energetickej bezpečnosti SR voblasti dodávok zemného plynu. The Slovak Foreign Policy Association, $1-42$.

Fawn, R. (2014). Visegrad's Place in the EU since Accession in 2004: "Western" Perceptions. International Issues \& Slovak Foreign Policy Affairs, 23 (1-2), 3-24.

Fedorov, Y.E. (2013). Continuity and Change in Russia's Policy toward Central and Eastern Europe. Communist and Post-Communist Studies, 46 (3), 315-326. DOI: 10.1016/j.postcomstud.2013.06.003

Gerasymchuk, S. (2014). Visegrad Group's Solidarity in 2004-2014: Tested by Ukrainian Crisis. International Issues \& Slovak Foreign Policy Affairs, 23 (1-2), 42-54.

Gressel, G. (2017). Fellow Travellers: Russia, anti-Westernism, and Europe's Political Parties. European Council on Foreign Relations Brief Policy, 225, 1-16. URL: https://www.ecfr.eu/page/-/ECFR225_-_FELLOW_ TRAVELLERS1.pdf (accessed: 25.11.2019).

Gyárfášová, O. \& Mesežnikov, G. (2016). 25 Years of the V4 as Seen by the Public. Bratislava.

Kucharczyk, J. \& Mesežnikov, G. (Eds.). (2015). Diverging Voices, Converging Policies: The Visegrad States' Reactions to the Russia-Ukraine Conflict. Warsaw: Heinrich-Böll-Stiftung.

Marušiak, J. (2015). Russia and the Visegrad Group - More Than a Foreign Policy Issue. International Issues \& Slovak Foreign Policy Affairs, 24 (1-2), $28-46$.

Marušiak, J. (2013a). Slovakia's Eastern Policy - from the Trojan Horse of Russia to Eastern Multivectoralism. International Issues \& Slovak Foreign Policy Affairs, $22(1-2), 42-70$.

Marušiak, J. (Eds.). (2013b). Internal Cohesion of the Visegrad Group. Bratislava: Veda, Publishing house of the Slovak Academy of Sciences.

Mišík, M. (2012). Crisis as Remedy? The 2009 Gas Crisis and Its Influence on the Increase of Energy Security within Visegrad Group Countries. International Issues \& Slovak Foreign Policy Affairs, 21 (1-2), 56-72.

Pakulski, J. (Eds.). (2016). The Visegrad Countries in Crisis. Warsaw: Collegium Civitas.

Póti, L. (2006). The Rediscovered Backyard: Central Europe in Russian Foreign Policy. Eager Eyes Fixed on Eurasia. 21st Century COE Program Slavic Eurasian Studies. July 6-7. Sapporo: Slavic Research Center, Hokkaido University. P. 113-133.

Racz, A. (2014). The Visegrad Cooperation: Central Europe Divided over Russia. L'Europe en Formation, 374 (4), 61-76. DOI:10.3917/eufor.374.0061

Sangtu, K. (2006). Russia's Choice of Alliance: Balancing or Bandwagoning. Eager Eyes Fixed on Eurasia. 21 st Century COE Program Slavic Eurasian Studies. July 6-7. Sapporo: Slavic Research Center, Hokkaido University. P. 149-161.

Shishelina, N.L. (2015). Russia's View of Relations with European Union and the Visegrad Group. International Issues \& Slovak Foreign Policy Affairs, 24 (1-2), 66-83.

Stojarová, V. (2018). Populist, Radical and Extremist Political Parties in Visegrad Countries Vis a Vis the Migration Crisis. In the Name of the People and the Nation in Central Europe. Open Political Science, 1 (1), 32-45. DOI: 10.1515/openps-2018-0001

Sydoruk, T. \& Tyshchenko, D. (2016). Positions of the Visegrad Four Countries and the Baltic States on the Russian-Ukrainian Conflict. Toruńskie Studia Międzynarodowe, 9 (1), 17-30.

Szomolányi, S. (2004). From a Difficult Case of Transition to a Consolidated Central European Democracy. Democracy and Market Economics in Central and Eastern Europe: Are New Institutions Being Consolidated. Slavic Research Center, Hokkaido University. P. 149-188.

Szomolányi, S. (2000). Why Slovakia's Transition Trajectory Has Been so Difficult? Társadalom és gazdaság Közép- és Kelet-Európában / Society and Economy in Central and Eastern Europe, 22 (1), 60-86. DOI: $10.2307 / 41468455$

Tarnawski, M. (2015). Security of Gas Supply in the Countries of the Visegrád Group. Securitologia, 21 (1), $127-142$.

\footnotetext{
About the author: Višňovský Radovan - PhD student, International Relations and World Politics programme, Saint-Petersburg State University (e-mail: visnovskyr@gmail.com).
}

Сведения об авторе: Вишнёвский Радован - аспирант, программа «Международные отношения и мировая политика» Санкт-Петербургского государственного университета (СПбГУ) (e-mail: visnovskyr@gmail.com). 